\title{
Optimization of Seed Germination, Callus Induction, and Secondary Metabolites Production in Allium Jesdianum: Elicitation by Methyl Jasmonate and Putrescine
}

\section{Esmat Yazdanian}

Department of Natural Resources, Isfahan University of Technology, Iran

Pooran Golkar ( $\sim$ poorangolkar@gmail.com )

Research Institute for Biotechnology and Bioengineering, Isfahan University of Technology, Isfahan, Iran. https://orcid.org/0000-0002-0547-178X

\section{Mohammad Reza Vahabi}

Department of Natural Resources, Isfahan University of Technology, Iran.

\section{Marzieh Taghizadeh}

University of Isfahan

\section{Research Article}

Keywords: Antioxidant activity, callus, total phenolics content, polyamines

Posted Date: February 15th, 2021

DOI: https://doi.org/10.21203/rs.3.rs-216603/v1

License: (1) This work is licensed under a Creative Commons Attribution 4.0 International License.

Read Full License 


\section{Abstract}

Allium jesdianum is considered as the most important genera of the Liliaceae family with various pharmacological properties. The present study was carried out to determine the best pre-germination treatment in A. jesdianum. The highest seed germination (58.33\%) was observed at chemical treatment including the combination of a-naphthaleneacetic acid $\left(1 \mathrm{mgL}^{-1}\right)$ and benzyl aminopurine $\left(3 \mathrm{mgL}^{-1}\right)$ on Murashige and Skoog (MS) media. The highest callus induction ( $86.7 \%$ ) was observed at MS/2 media, which was supplemented by NAA $\left(1 \mathrm{mgL}^{-1}\right)$ and BAP $\left(3 \mathrm{mgL}^{-1}\right)$ from hypocotyl explants. Two elicitors including methyl jasmonate $(\mathrm{MeJ})(0,25,50$, and $100 \mu \mathrm{M})$ and putrescine $(\mathrm{Pu})(0,0.5$, and $1 \mathrm{mM})$ were used to investigate their effects on lipid peroxidation, callus growth traits, total phenolics content (TPC), the contents of total flavonoids (TFD), total flavonols (TFL), anthocyanin, total chlorophyll, total carotenoids and on antioxidant activity through DPPH (1,1-diphenyl-2-picrylhydrazyl) method under callus culture. The results showed the superiority of MeJ over Pu for increasing the secondary metabolites and antioxidant activity in callused of $A$. Jesdianum, compared to the control. The highest TPC (6.02 $\left.\mathrm{mg} \mathrm{GAEg}^{-1} \mathrm{FW}\right)$, TFD (0.52 $\left.\mathrm{mg} \mathrm{QEg}^{-1} \mathrm{FW}\right)$, and TFL (0.39 $\mathrm{mg} \mathrm{QEg}^{-1} \mathrm{FW}$ ) were observed under $50 \mu \mathrm{M}$ of MeJ. Meanwhile, the highest value for anthocyanin $\left(8.99 \mu \mathrm{mol} \mathrm{g}^{-1} \mathrm{FW}\right)$ was achieved at $25 \mu \mathrm{M}$ of MeJ. The highest DPPH activities were observed at 50 and $100 \mu \mathrm{M}$ of MeJ. Putrescine $(0.5 \mathrm{mM})$ elicitation showed only superiority for callus growth rate $\left(0.53 \mathrm{~mm}\right.$ day $\left.{ }^{-1}\right)$ and carotenoids $\left(0.045 \mathrm{mg} \mathrm{g}^{-1}\right.$ DW). In this study, effective seed germination and elicitation of $A$. Jesdianum callus cultures were developed for the first time. Thus, new protocols could be suitable for future studies in biotechnological aspects of this medicinal plant.

\section{Introduction}

Medicinal plants are traditionally considered among the main sources of secondary metabolites (SMs) and natural drugs with antioxidant properties (Yue et al. 2016). The discovery of new natural products with medicinal characteristics has been recently the subject of intense research (Yue et al. 2016). These SMs are important sources for producing different cosmetics, fragrances, flavors, food additives, and pharmaceutical and industrial products (Namdeo 2007; Erb and Kliebenstein, 2020). The technique of plant cell culture is based on a set of biotechnological methods for producing valuable plant-specific SMs on large scale, independent from environmental conditions (Vanisree et al. 2004; Smetanska 2008). In vitro culture techniques have been used for enhancing different phytochemical compounds as a promising bio-production way for desired and/or rare natural products (Dias et al. 2016; Yue et al. 2016). In this regard, in vitro elicitation is an efficient strategy to promote plants' defense mechanism for scavenging the reactive oxygen species (ROS) (Matkowski 2008). The subsequent modulating and production of plant SMs occurs by regulating the expression of genes that are involved in producing key enzymes implicated in the biosynthesis of different defense-related compounds as phytoalexins, flavones, flavonoids phenolics, and other bioactive compounds (Namdeo 2007) under the elicitation process. To enhance the production of these components, chemical elicitors have been widely applied in recent years as environmentally benign techniques (Narayani and Srivastava 2017). In vitro production of 
worthy compounds using callus culture has been very well recognized and is being used widely for different industrial applications (Narayani and Srivastava 2017).

Jasmonates (JA) is considered an important chemical messenger for different signal transduction pathways in different ways such as elicitation for the biosynthesis of SMs, and participating in enzyme activation under environmental stresses (Thiruvengadam et al. 2015; Nabi et al. 2021). Methyl jasmonate (MeJ) is an essential signaling compound in the intracellular signal cascades that ultimately leads to the hyper production of various SMs (Narayani and Srivastava 2017; Singh and Dwivedi 2018). According to previous studies in the stimulation of flavonoids and phenolic compounds production, jasmonates and their derivatives such as MeJ have been used in many plant families as elicitors under cell cultures (Gabr et al. 2016; Ho et al. 2016; Mendoza et al. 2018).

Polyamines (PAs), as a group of phytohormone-like aliphatic amine natural compounds, could play critical roles in the defense mechanism of plants against environmental stresses (Chen et al. 2019). PAs are involved in many important cellular processes such as cell viability, cell division, and its prolongation, protein synthesis, replication of DNA, response to different abiotic stresses by acting as defense signaling molecules and scavengers of free radicals, regulation of different physiological processes as embryogenesis, floral development, and fruit ripening and senescence (Jiménez Bremont et al. 2014; Rangan et al. 2014; Chen et al. 2019).

The putrescine $(\mathrm{Pu})$ with its plant formula as $\mathrm{C}_{4} \mathrm{H}_{12} \mathrm{~N}_{2} \cdot 2 \mathrm{H}_{2} \mathrm{O}$ is categorized as one of the plant hormones in the polyamines group (Jiménez Bremont, et al. 2014). This organic compound is considered as the primary source of other $\mathrm{PA}_{S}$ species such as spermidine and spermine (Jiménez Bremont et al. 2014; Rangan et al. 2014). Some studies have shown progressing effects of $\mathrm{PA}_{S}$ on increasing the plant tolerance to environmental stresses, but physiological responses to Pu as an elicitor has not been clear. Very few studies have been reported that the effect of exogenous $\mathrm{PA}_{\mathrm{s}}$ is enhanced for somatic embryogenesis and shoot regeneration in some plants such as Cucumis anguria L. (Thiruvengadam and Chung 2015), Dactylis glomerata L. (Li and Burritt 2003), and Nigella damascena L. (Klimek-Chodacka et al. 2020).

The genus Allium in the Liliaceae family secures its place among the top-ranked multipurpose medicinal plants with huge commercial values and food industries (Bhat 2020). There are some reports on the use of this genus in traditional medicine as an antioxidant, antibacterial (Kyung 2012; Pirbalouti 2019), antiviral (Bhat 2020), antiparasitic, antifungal (Bhat 2020), anti-protozoa, anti-inflammatory (Pirbalouti 2019), anticancer (Bhat 2020), anti-diabetic, and beneficial effects on curing the cardiovascular diseases (Lorigooini et al. 2015) and common cold treatments (Pirbalouti 2019).

Allium jesdianum Boiss ( $A$. jesdianum) is an important endemic, threatened, and underutilized plant species of Iran (known locally as "Bonsorkh" and "Yazdi onion") that grows in high altitudes (1800-2600 $\mathrm{m}$ ) of Zagros mountains in west and northwest regions of Iran (Kalantari et al. 2018; Pirbalouti 2019). This species is eaten raw or as a cooked vegetable or is used as a flavor additive to fresh or cooked foods 
in Iran. In the field cultivation, its propagation rate is very slow and it takes years to produce a new variety. In folk medicine of Iran, bulbs and leaves of this plant are used for the treatment of cold, kidney problems, and rheumatic pains (Pirbalouti 2019). Also, other medical properties as antibacterial (Dorosti et al. 2017) and anticancer (Dorosti et al. 2017) are reported for this valuable species. In this regard, many attempts have been made to isolate and exploit the active medicinal compounds from it. Considering the potential value of $A$. jesdianum cell or tissue cultures for biotechnological application, there is an urgent need to develop strategies for the protection and conservation of this genus by the development of its fast seed germination and in vitro conservation protocols.

The present work was aimed to study (a) the effects of physical and chemical pre-treatments on seed germination of $A$. jesdianum under in vitro culture, (b) the optimization of an efficient procedure for callus induction of $A$. jesdianum, and (c) establish an efficient strategy for enhancement in commercially vital SMs of $A$. jesdianum under elicitation by Pu and MeJ through callus cultures.

\section{Materials And Methods}

\subsection{Seed collection and seed germination experiments}

A. jesdianum seeds were gathered from the highland of Sabzkooh province $\left(31^{\circ} 27^{\prime} \mathrm{N} 52^{\circ} 40^{\prime} \mathrm{E}\right.$ mountain about 2,140 $\mathrm{m}$ height), in Chaharmahal-o-Bakhtiari region of Iran. A. jesdianum seeds were identified by the experts of Botanical Researcher of Department of Natural Resources, Isfahan University of Technology (IUT), Isfahan, Iran .The seeds were surface disinfected with $70 \%$ (v/v) ethanol for $90 \mathrm{sec}$ and surface sterilized thoroughly with $2 \%(\mathrm{v} / \mathrm{v})$ sodium hypochlorite for $15 \mathrm{~min}$. The seeds were then rinsed three times with sterile water to remove the remaining amount of disinfection liquid. The sterilized seeds were then placed on to MS medium (Murashige and Skoog, 1962) (Duchefa, Netherland) containing $0.8 \%$ $(\mathrm{w} / \mathrm{v})$ agar (Sigma-Aldrich, USA) and $3 \%(\mathrm{w} / \mathrm{v})$ sucrose and $0.1 \mathrm{mg} \mathrm{L}^{-1}$ myoinositol, with different chemical treatments. The seeds were cultured on MS medium with several chemical treatments, including: plant growth regulators as (1-naphthaleneacetic acid [NAA: Duchefa], 6-Benzylaminopurine [BAP: Duchefa], 2,4-dichlorophenoxyacetic[2,4-D: Duchefa] and gibberellic acid [GA $\mathrm{GA}_{3}$ : Duchefa] ). Other seeds were treated with physical pre-treatments such as $\mathrm{NaCl}(1 \mathrm{M})$, cold $\left(4^{\circ} \mathrm{C}\right.$ for four weeks) and mechanical scarification, then were cultured on MS medium supplemented with different PGRs combinations (Table 1). The seeds were cultured on MS medium as a control group. In order to determine the effect of physical and chemical pretreatments on germination experiments were conducted in the photoperiod of $16 / 8$ (light/dark) at $23 \pm 2^{\circ} \mathrm{C}$ for seed germination. 
Table 1

Effect of different pre-treatments on germination traits of $A$. jesdianum under in vitro culture conditions.

No. Treatments

' MS (Control)

$2 \mathrm{MS}+\mathrm{GA}_{3}\left(10 \mathrm{mg} \mathrm{L}^{-1}\right)$

$4 \quad$ MS + mechanical scarification

$3 \quad \mathrm{MS}+\mathrm{GA}\left(10 \mathrm{mg} \mathrm{L}^{-1}\right)+$ mechanical

5

10 Cold $\left(4^{\circ} \mathrm{C}\right.$ for 3 weeks $)$

$6 \quad \mathrm{MS}+\mathrm{GA}_{3}\left(3 \mathrm{mg} \mathrm{L}^{-1}\right)+\mathrm{Kin}\left(5 \mathrm{mg} \mathrm{L}^{-1}\right)$

$7 \quad \mathrm{MS}+2,4-\mathrm{D}\left(2 \mathrm{mg} \mathrm{L}^{-1}\right)+\mathrm{NaCl}(1 \mathrm{M})$

$8 \quad \mathrm{MS}+2,4-\mathrm{D}\left(2 \mathrm{mg} \mathrm{L}^{-1}\right)+$ mechanical scarification

$9 \quad \mathrm{MS}+\mathrm{NAA}\left(1 \mathrm{mg} \mathrm{L}^{-1}\right)+\mathrm{BAP}\left(3 \mathrm{mg} \mathrm{L}^{-1}\right)$

11

$\mathrm{MS} / 2+\left(\mathrm{NAA} 1 \mathrm{mg} \mathrm{L}^{-1}+\mathrm{BAP} 3 \mathrm{mg} \mathrm{L}^{-1}\right)+$ mechanical scarification

12

$\mathrm{MS} / 4+\left(\mathrm{NAA} 1 \mathrm{mg} \mathrm{L}^{-1}+\mathrm{BAP} 3 \mathrm{mg} \mathrm{L}^{-1}\right)+$ mechanical scarification

13

$\mathrm{MS} / 4$ + (NAA $\left.3 \mathrm{mg} \mathrm{L}-1+\mathrm{BAP} 1 \mathrm{mg} \mathrm{L}^{-1}\right)+$ mechanical scarification

14

$\mathrm{MS} / 4+\left(\mathrm{NAA} 1 \mathrm{mg} \mathrm{L}^{-1}+\mathrm{BAP} 3 \mathrm{mg} \mathrm{L}^{-1}\right)+$ cold

15

$\mathrm{MS} / 4+\left(\mathrm{NAA} 3 \mathrm{mg} \mathrm{L}^{-1}+\mathrm{BAP} 1 \mathrm{mg} \mathrm{L}{ }^{-1}\right)+$ cold

16

$\mathrm{MS} / 2+\left(\mathrm{GA}_{3} 10 \mathrm{mg} \mathrm{L}^{-1}\right)+$ cold
GP (\%)

GR (mm day ${ }^{-}$

1)

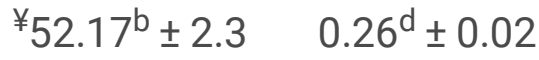

$38.23^{\mathrm{c}} \pm 1.15 \quad 0.1^{\mathrm{ef}} \pm 0.028$

$16.67^{\mathrm{fgh}} \pm$

$0.06^{\mathrm{ef}} \pm 0.017$

1.73

$25^{\mathrm{e}} \pm 1.15$

$0.05^{\mathrm{ef}} \pm$

0.0057

$20^{f} \pm 1.73$

$0.02^{\mathrm{ef}} \pm 0.005$

$24.66^{\mathrm{e}} \pm 0.88$

$0.1^{\text {ef }} \pm 0.03$

$35.71^{\mathrm{cd}} \pm$

$0.1^{\mathrm{ef}} \pm 0.0746$

1.73

$20^{f} \pm 2.3$

$0.01^{f} \pm 0.002$

$12.5^{\mathrm{h}} \pm 1.15 \quad 0.04^{\mathrm{ef}} \pm 0.01$

$58.33^{\mathrm{a}} \pm 1.73$

$0.12^{\mathrm{e}} \pm 0.02$

$32^{d} \pm 1.15$

$0.72^{\mathrm{c}} \pm 0.04$

$0^{\mathrm{i}}$

$0^{f}$

$0^{\mathrm{i}}$

$0^{f}$

$13.36^{\mathrm{gh}} \pm$

$1.01^{b} \pm 0.055$

1.27

$17.5^{\mathrm{fg}} \pm 2.3$

$1.74^{\mathrm{a}} \pm 0.11$

$0^{\mathrm{i}}$

$0^{f}$

I: MS: Murashige and Skoog media; $\mathrm{GA}_{3}$ : gibberellic acid; NAA: naphthalene acetic acid; BAP: benzyl amino purine; 2,4D: 2,4-Dichlorophenoxyacetic acid ; $¥$ : means \pm standard deviations; in each column the means with similar English letter are not significant at $P<0.01$.

\subsection{Germination related traits}


To determine the optimal parameters of seed germination, the impacts of certain physical and chemical pretreatments on germination rate and germination percent were evaluated. The germination process was observed by emerging the first radicle. The number of seeds germinated in each pre-treatment was recorded every two days. The germination percentage was calculated using the following equation at the end of the germination period (Amoakoh et al. 2017): Germination percentage (GP) $=$ (number of seeds germinated/number of planted seeds) $\times 100$. The germination rate (GR) was calculated as the sum of the percentage of seed germination in each count by the time elapsed since the beginning of the test (Amoakoh et al. 2017). The mathematical expression of this criteria is expressed as GR $=\sum$ percentage of germination/days to the final count.

\subsection{Optimization of callus induction}

For callus induction, two different explants (seed and hypocotyl) were used. The hypocotyl (4-6 mm long) and sterile seed explants were cultured in MS basal medium containing $3 \%(\mathrm{w} / \mathrm{v})$ sucrose and $0.8 \%$ $(\mathrm{w} / \mathrm{v})$ agar, which supplemented with various combination of PGRs including different concentrations of auxins and cytokinins including ( $\left.1 \mathrm{mg} \mathrm{L}^{-1} \mathrm{NAA}+3 \mathrm{mg} \mathrm{L}^{-1} \mathrm{BAP}\right),\left(3 \mathrm{mg} \mathrm{L}^{-1} \mathrm{NAA}+1 \mathrm{mg} \mathrm{L}^{-1} \mathrm{BAP}\right),(1 \mathrm{mg}$ $\left.\mathrm{L}^{-1} \mathrm{BAP}+2 \mathrm{mg} \mathrm{L}^{-1} 2,4 \mathrm{D}\right)$ and $\left(2 \mathrm{mg} \mathrm{L}^{-1} \mathrm{BAP}+1 \mathrm{mg} \mathrm{L}^{-1} 2,4 \mathrm{D}\right)$. The $\mathrm{pH}$ of the culture media was adjusted to 5.8 before autoclaving for $20 \mathrm{~min}$ at a pressure of $1.06 \mathrm{~kg} / \mathrm{cm}^{2}$. Explants were cultured on each medium with six replicates under $16 \mathrm{~h}$ light/ $8 \mathrm{~h}$ dark photoperiod at $25 \pm 2^{\circ} \mathrm{C}$ for two months in the culture chamber. The callus induction percent $(\mathrm{Cl})$ and callus growth rate (CGR) were measured. To calculate $\mathrm{Cl}$, callus induction was measured using the following equation: [(n/N) $\times 100]$, at the end of two month from the initial of callus induction. In this formulae, " $n$ " represents the total number of callus explants, and " $\mathrm{N}$ " is the total number of cultured explants. Callus growth rate was calculated according to the means of callus growth rates ( $\mathrm{mm}$ day $^{-1}$ ) at every 15 days in 2 months period (Golkar et al 2019).

\subsection{Methyl jasmonate and putrescine elicitation}

Two independent experiments were done to study the effects of different concentration of MeJ and Pu on phytochemical traits of $A$. jesdianum. Methyl jasmonate (Sigma Aldrich, USA) was dissolved in pure ethanol and filtered using a micro filter of $0.22 \mu$ pore size and then added to the MS medium. Putrescine (Sigma-Aldrich, USA) was prepared in doubled distilled water and the $\mathrm{pH}$ was adjusted to 5.8. Filtersterilized (0.22- $\mu \mathrm{m}$ filter) putrescine were added to the MS medium. For elicitation purposes, after two months of callus induction, the friable and white callus as equal fragments were transferred to new MS media containing $3 \mathrm{mg} \mathrm{L}^{-1}$ of BAP and $1 \mathrm{mg} \mathrm{L}^{-1}$ of NAA under different concentrations of MeJ $(0,25,50$, and $100 \mu \mathrm{M})$ and $\mathrm{Pu}(0,0.5$, and $1 \mathrm{mM})$. All treatments were incubated in the $16 \mathrm{~h}$ light/ $8 \mathrm{~h}$ dark photoperiod at $24 \pm 2{ }^{\circ} \mathrm{C}$ in the culture chamber. The concentrations of MeJ and Put were chosen based on some preliminary experimental works and literature review. Different phytochemical characteristics were measured under MeJ and Put elicitation after 4 weeks of incubation.

\subsection{Physiological characteristics}


Callus relative fresh weight (RFW) was according to this formulae: $\mathrm{RFW}=\left(F W_{2}-F_{1}\right) /$ days, where, $F W_{1}$ is the fresh weight of the callus at the initiation of the elicitation and $\mathrm{FW}_{2}$ is the final fresh weight of the callus at the final day post of elicitation process. CGR was calculated at 15, 30, 45 and 60 day post callus transferring to elicitation media.

\subsection{Lipid peroxidation assay}

The amount of cell membrane damage was determined by measuring malondialdehyde (MDA) as the end product of peroxidation of membrane lipids. For this assay, $0.2 \mathrm{~g}$ of fresh calli were homogenized with $3 \mathrm{~mL}$ trichloroacetic acid (TCA) $(0.1 \% \mathrm{w} / \mathrm{v})$ (Merck, Com.). The homogenate was centrifuged for 30 min at $4000 \mathrm{rpm}$. Then the supernatant $(5 \mathrm{~mL})$ was collected and mixed with $4 \mathrm{~mL}$ of thiobarbituric acid (TBA) $(0.5 \% \mathrm{w} / \mathrm{v})$ and $20 \% \mathrm{TCA}(\mathrm{w} / \mathrm{v})$. Then, the sample was heated at $95^{\circ} \mathrm{C}$ for $25 \mathrm{~min}$ and then placed on ice bath. Its absorbance was measured at 532 and $600 \mathrm{~nm}$ with a spectrophotometer. The content of MDA was calculated by an extinction coefficient of $155 \mathrm{mM}^{-1} \mathrm{~cm}^{-1}$ and expressed as $\mu \mathrm{mol} \mathrm{g}^{-1} \mathrm{FW}$ (Heath and Packer, 1968).

\subsection{Methanolic callus extract}

At first, $0.5 \mathrm{~g}$ of completely dried callus were powdered and added to $10 \mathrm{~mL}$ of diethyl ether $\left.\left[\mathrm{C}_{2} \mathrm{H}_{5}\right)_{2} \mathrm{O}\right]$. The mixture was well mixed and stored in a refrigerator for $24 \mathrm{~h}$. For complete evaporation of diethyl ether, the supernatant was transferred to dryer. Then $10 \mathrm{~mL}$ of $80 \%$ methanol were added to that purified supernatant and then filtered using a $0.4 \mu \mathrm{m}$ filter.

\subsection{Determination of total phenolic content}

Based on the Folin-Ciocalteau reagent method described by Singleton et al. (1999) total phenolics content (TPC) was determined. In brief, $0.2 \mathrm{~g}$ fresh weight of celli were homogenized with $3 \mathrm{ml} \mathrm{CH}_{3} \mathrm{OH}$ (Merck. Com) and centrifuged at $4000 \mathrm{rpm}$ for $25 \mathrm{~min}$. Then, methanolic extract $(0.5 \mathrm{~mL})$ was mixed with $2.5 \mathrm{~mL}$ of Folin-Ciocalteau reagent (Sigma- Aldrich, Com), followed by the addition of $2.0 \mathrm{~mL}$ of $7 \%$ $\mathrm{Na} \triangle \mathrm{CO} \otimes$ solution. The mixture was disposed in the dark for $90 \mathrm{~min}$ at room temperature. The absorbance of the supernatant was recorded at $765 \mathrm{~nm}$ against the reagent blank by a spectrophotometer. The amount of TPC was then quantified by the method of calibration curve using gallic acid $\left(\mathrm{GA}_{3}\right)$ (SigmaAldrich, Com) as standard.

\subsection{Determination of total flavonoids and total favonols content}

Total flavonoids (TFD) and total flavonols (TFL) contents were determined spectro- photo metrically using the method of Miliauskas et al. (2004). In brief, $0.2 \mathrm{~g}$ fresh calli was ground in $3 \mathrm{~mL}$ of methanol and centrifuged at 4000 rpm for $25 \mathrm{~min}$. Then, supernatant was used to assay TFD and TFL contents. For estimation of TFL, $0.5 \mathrm{~mL}$ of methanolic extract, $0.5 \mathrm{~mL}$ of $\mathrm{AlCl}_{3}(2 \% \mathrm{w} / \mathrm{v})$ solution and $1.5 \mathrm{~mL}$ of sodium acetate $(5 \% \mathrm{w} / \mathrm{v})$ were mixed and after $90 \mathrm{~min}$ of incubation at room temperature, the absorbance of mixture was measured at $445 \mathrm{~nm}$. For total flavonoid $0.5 \mathrm{~mL}$ of methanolic extract, $125 \mu \mathrm{L}$ of $\mathrm{AlCl}_{3}$ 
solution (\%10 w/v) and $125 \mu \mathrm{L}$ of $\mathrm{CH}_{3} \mathrm{COOK}(1 \mathrm{M})$ were mixed and the samples were kept at room temperature for $30 \mathrm{~min}$. A spectrophotometer was used to measure the absorbance of the reaction mixture at $415 \mathrm{~nm}$ with. The contents of total flavonoids and flavonols were expressed as $\mathrm{mg}$ quercetin (QE) equivalents per gram of fresh mass ( $\mathrm{mg} \mathrm{QE} \mathrm{g}^{-1} \mathrm{FW}$ ).

\subsection{Determination of anthocyanin}

At the first step, $2 \mathrm{~mL}$ acidified methanol $(1 \% \mathrm{HCl})$ was used for homogenizing the fresh calli $(0.2 \mathrm{~g})$ at room temperature (Hara et al. 2003). After one day, the total extract was centrifuged for 25 min at 4000 $\mathrm{rpm}$. Then, the content of anthocyanin was determined by spectrophotometer at wave length of $511 \mathrm{~nm}$ based on the extinction coefficient of Raphanusin $\left(33000 \mathrm{M}^{-1} \mathrm{~cm}^{-1}\right)$.

\subsection{Determination of photosynthetic pigments}

Carotenoids and chlorophyll contents were determined according to the method of Lichtenthaler and Buschmann (2001). Acetone (80\%) (Merck, Com.) was used for these pigments extraction from fresh calluses. For carotenoids, absorption spectra of the extracts were measured at 470, 652 and $665 \mathrm{~nm}$ and its concentrations were calculated according to the Lichtenthaler equations.

\subsection{DPPH radical scavenging activity}

Radical scavenging activities of safflower calli were determined by DPPH assay (Golkar and Taghizadeh, 2018). The methanolic extract $(20 \mu \mathrm{L})$ was added to $1 \mathrm{~mL}$ of $50 \mu \mathrm{M}$ DPPH (Sigma, Aldrich) solution in methanol. The prepared extracts ranged from 0 to $250 \mu \mathrm{g} \mathrm{mL}^{-1}$. The mixtures were mixed and incubated in the dark condition for $20 \mathrm{~min}$. The reduction of DPPH absorption was measured at $515 \mathrm{~nm}$. The positive control was ascorbic acid (Sigma, Aldrich). The DPPH radical scavenging activity was calculated using the equation: Inhibition concentration (inhibition percentage: IP \%) $=($ absorbance control absorbance sample)/(absorbance control) $\times 100$.

\subsection{Statistical analysis}

This study elicitation section was carried out as a factorial based on a completely randomized design with six replications. The germination and callus induction experiments were carried out as a completely randomized design with six replications. The analysis of variance done using SAS software version 9.3 (SAS Institute, 2011). Then, mean comparisons ( \pm standard deviations) were carried out using Fisher's least significant difference (LSD $\left.{ }_{5 \%}\right)$ test.

\section{Results And Discussion 3.1 Seed germination}


The optimization of germination is considered as a major gap in A. jesdianum. To the best of our knowledge, no previous study has reported the optimization in germination through seed in A. jesdianum. Some studies have optimized germination in some Allium species (Kamenetsky and Gutterman 2000). Some treatments such as scarification and darkness helped break the dormancy of some genus as $A$. suworowii, $A$. aflatunense, and A. altissimum at cold temperatures (Kamenetsky and Gutterman 2000). This study, for the first time, evaluated the effects of different treatments to triggering germination of $A$. Jesdianum under in vitro culture. Different treatments including mechanical (scarification), chemical (different combination of plant growth regulators), and thermal conditions (cold temperature) were applied to optimize the germination ratio in A. jesdianum (Table 1). Evaluation of germination under different treatments showed extensive variation in GP in about 30-45 days after initiating the treatment. There was a statistically significant difference $(P<0.01)$ in GP and GR between different pre-germination treatments (Table S1). According to the data in Table 1, the maximum GP $(58.33 \%)$ was observed in seeds treated with treatment including MS + NAA $\left(1 \mathrm{mgL}^{-1}\right)+\mathrm{BAP}\left(3 \mathrm{mg} \mathrm{L}^{-1}\right)$. On the other hand, the minimum of GP $(0 \%)$ was observed in three treatments including 1$)\left[\mathrm{MS} / 4+\left(\mathrm{NAA} 1 \mathrm{mgL}^{-1}+\mathrm{BAP} 3\right.\right.$ $\left.\mathrm{mgL}^{-1}\right)+$ mechanical], 2) $\left[\mathrm{MS} / 4+\left(\mathrm{NAA} 3 \mathrm{mgL}^{-1}+\mathrm{BAP} 1 \mathrm{mgL}^{-1}\right)+\right.$ mechanical], and 3$)$ and $\left[\mathrm{MS} / 2+\left(\mathrm{GA}_{3}\right.\right.$ $\left.10 \mathrm{mgL}^{-1}\right)+$ cold] (Table 1) (Table 1). The differences in the GP of $A$. jesdianum seeds suggests the significant impact of various pretreatments on breaking the seed dormancy in this species. The germination rate varied from $1.74\left(\mathrm{~mm}^{\text {day }}{ }^{-1}\right)$ in the treatment of $\left[\mathrm{MS} / 4+\left(\mathrm{NAA} 3 \mathrm{mgL}^{-1}+\mathrm{BAP} 1 \mathrm{mgL}^{-}\right.\right.$ $\left.{ }^{1}\right)+$ cold] to $0.01\left(\mathrm{~mm}\right.$ day $\left.{ }^{-1}\right)$ in treatment of $\mathrm{MS}+2,4 \mathrm{D}\left(2 \mathrm{mgL}^{-1}\right)+\mathrm{NaCl}(1 \mathrm{M})($ Table 1$)$. The phenomenon of seed dormancy in seeds of some medicinal plants is usually linked with internal factors such as physiological dormancy or physical barriers that cover the seed coat and/or the enclosed embryo (Abbas et al., 2018). Reviewing the previous investigations, different treatments such as mechanical scarification and cold-water stress were found to be effective for germination in seeds of A. jesdianum; however, chemical treatments had the most effect on breaking seed dormancy. Therefore, from the above findings, it can be inferred that dormancy of the seeds of $A$. jesdianum was probably associated with the enclosed covering around the embryo. The seeds under control condition gave a similarly high GP (52.17\%) but seeds took a long time to germinate, similar to germination in Parkia biglobosa (Abbas et al. 2018). It seems that the ecological background of the natural habitat for seed collection region and harvesting time play predominant roles in seed germination capacity in A. jesdianum. The optimized protocol could be used for rapid propagation of this plant under in vitro conditions.

\subsection{Callus induction}

Despite the role of $A$. jesdianum as an important medicinal plant, no research has focused on using in vitro cultures in this neglected species. In the present investigation, callus initiation from explants (hypocotyl and seeds) were observed within 14-18 days on all medium compositions (Fig. 1). The induced calli grew into yellow-to-greenish color with a semi-friable structure on four different media. The growth of calli were fast after their induction. 
Analysis of variance showed a significant effect of treatments on $\mathrm{Cl}$ and CGR (Table S2). Callus induction in all tested PGRs and explants were effective (Table 1). The effects of different PGRs (2,4-D, NAA and BAP) and explants (seed and hypocotyl) on callus induction (\%) and callus growth rate of $A$. jesdianum is presented at Table 2. As seems, this is the first report regarding the optimized protocol for callus induction in A. jesdianum. According to Table 2, MS/2 media supplemented with $1 \mathrm{mgL}^{-1} \mathrm{NAA}$ and 3 $\mathrm{mgL}^{-1}$ BAP were recognized as the best combination for highest callus induction ( $83.92 \%$ ) in seeds explants of $A$. jesdianum (Table 2), which showed no significant difference with MS/2 media supplemented with NAA $\left(1 \mathrm{mg} \mathrm{L}^{-1}\right)+$ BAP $\left(3 \mathrm{mgL}^{-1}\right)$ from hypocotyl explants (Table 2$)$. The least value for $\mathrm{Cl}$ (42.01\%) was denoted to MS/2 media which was supplemented by $2 \mathrm{mgL}^{-1} \mathrm{BAP}$ and $1 \mathrm{mgL}^{-1} 2,4-$ D (Table 2). These findings showed no callus induction on complete MS media for this species. So it could be resulted that lower concentrations of macro and micro elements was better for cells differentiation from explants in this genus. The good response of hypocotyl explants could be due to homogenous cell nature and easy availability of growth substances to each cell of homogenous tissues, hypocotyl explants showed high potential for callus induction. The combined effects of auxins and cytokinins have been considered as essential factors for callus induction in A. jesdianum. Comparison of four different treatment implied that higher concentrations of BAP (as cytokinin group) than 2,4D and NAA (as auxins), could be promotive for more frequency in callus initiation and its growth in A.jesdianum. This finding was similar to previous reports in Allium schoenoprasum L (Zdravkovic'-Korac et al. 2010) and Allium Ampeloprasum L. (Monemi et al. 2014). Different with this finding, necessity of higher doses of auxins rather than cytokinins is emphasized for callus induction in other species in Liliaceae family as Allium sativum (Dixit et al. 2013) Allium cepa (Bekheet et al. 2006) and micropropagation in Allium neapolitanum Cirillo (Stelmaszczuk and Kozak 2013). According to reports of Khar et al. (2005), lonely application of 2,4-D ( $\left.0.5 \mathrm{mgL}^{-1}\right)$ was optimized for maximum callus formation in Allium cepa L. These inconsistencies can be due to the effects of many factors on callus induction in Allium species such as genus, genotypes, type of explants, medium composition and plant growth used (Stelmaszczuk and Kozak 2013). The highest $\left(0.48 \mathrm{~mm}\right.$ day $\left.^{-1}\right)$ callus growth rate were observed in MS/2 media supplemented with $1 \mathrm{mgL}^{-1} \mathrm{NAA}$ and $3 \mathrm{mgL}^{-1} \mathrm{BAP}$ (Table 2), but the lowest one $\left(0.18 \mathrm{~mm}\right.$ day $\left.^{-1}\right)$ was observed at MS/2 media which was supported by $2 \mathrm{mgL}^{-1} \mathrm{BAP}+1 \mathrm{mgL}^{-1} 2,4 \mathrm{D}$ (Table 2). This implied at a positive interactive effects of these concentrations of BAP and $2,4 \mathrm{D}$ on used explant for enhancing the callus growth. 
Table 2

The effects of combination of different plant growth regulators on the callus-related traits of $A$. jesdianum

\begin{tabular}{|c|c|c|c|c|}
\hline Explant & Plant growth regulators treatments & $\begin{array}{l}\text { Callus color and } \\
\text { texture }\end{array}$ & $\begin{array}{l}\mathrm{Cl} \\
(\%)\end{array}$ & $\begin{array}{l}\text { CGR } \\
\text { ( } \text { mmday }^{-} \\
\left.{ }^{1}\right)\end{array}$ \\
\hline Seed & $\begin{array}{l}\left.\text { NAA } 1 \mathrm{mg} \mathrm{L}^{-1}\right)+\mathrm{BAP}\left(3 \mathrm{mg} \mathrm{L}^{-1}\right) \\
\text { )MS } / 2+\end{array}$ & $\begin{array}{l}\text { yellow- } \\
\text { greenish/friable }\end{array}$ & $\begin{array}{l}¥ 83.92^{\mathrm{a}} \pm \\
8.80\end{array}$ & $0_{0.48^{a}}^{a} \pm$ \\
\hline Hypocotyl & $\begin{array}{l}\mathrm{MS} / 2+\mathrm{BAP}\left(1 \mathrm{mg} \mathrm{L}^{-1}\right)+2,4 \mathrm{D}(2 \\
\left.\mathrm{mg} \mathrm{L}^{-1}\right)\end{array}$ & yellow/ friable & $\begin{array}{l}78.33^{\mathrm{a}} \pm \\
7.35\end{array}$ & $\begin{array}{l}0.23^{b c} \pm \\
0.1\end{array}$ \\
\hline Hypocotyl & $\begin{array}{l}\left.\text { BAP } 2 \mathrm{mg} \mathrm{L}^{-1}\right)+2,4 \mathrm{D}\left(1 \mathrm{mg} \mathrm{L}^{-1}\right) \\
) \mathrm{MS} / 2+\end{array}$ & yellow/ friable & $\begin{array}{l}42.01^{\mathrm{b}} \pm \\
22.77^{-}\end{array}$ & $\begin{array}{l}0.18^{\mathrm{c}} \pm \\
0.08\end{array}$ \\
\hline Hypocotyl & $\begin{array}{l}\mathrm{MS} / 2+\mathrm{NAA}\left(1 \mathrm{mg} \mathrm{L}^{-1}\right)+\mathrm{BAP}(3 \\
\left.\mathrm{mg} \mathrm{L}^{-1}\right)\end{array}$ & $\begin{array}{l}\text { pale-yellow / } \\
\text { friable }\end{array}$ & $86.7^{a} \pm 8.12$ & $0.23^{\mathrm{b}} \pm 0.1$ \\
\hline
\end{tabular}

$¥:$ means \pm standard deviations; in each column the means with similar English letter are not significant at $P<0.01$. Cl: callus induction; CGR: callus growth rate.

\subsection{Elicitation effects on different studied traits under callus culture}

To synthesize SMs under callus cultures, appropriate techniques need to be developed efficiently (Smetanska 2008). It is well known that in vitro culture systems may offer much more efficient production of SMs if culture conditions are well optimized (Mulabagal et al. 2004). Among chemical elicitors, MeJ has been used widely for in vitro elicitation studies as callus culture systems (Singh and Dwivedi 2018), but rare studies demonstrated the effects of Pu elicitation on SMs under callus culture (Sudha et al. 2003). The effects of different concentrations of MeJ and Pu on callus-related traits, MDA content, different phenolic compounds, photosynthetic pigments (chlorophyll and carotenoids), and antioxidant activity were evaluated after elicitation. According to the analysis of variance (ANOVA) results, there was a statistically significant difference for all studied traits under elicitation (Table S3).

\subsubsection{Callus growth traits}

When studying the callus growth, the responses of relative fresh weight and callus growth rate were evaluated to different doses of MeJ and Pu. Overall, a decrease in RFW was observed in response to most of the treatments compared to the control (Table 3). The least content for RFW (0.60) was observed at $100 \mu \mathrm{M}$ concentration of MeJ rather than control (0.42) (Table 3). The stressor effects of both used elicitors (especially at higher concentrations) reduced the RFW. This is probably due to the inhibitory effects of elicitors on cell growth and capacity of cell osmotic adjustment, which increase the requirement for maintaining turgor of the growing cells, consuming energy, and decrease in callus growth 
(Golkar et al. 2019). Similarly, higher concentrations of other elicitors phenylalanine and mevalonic acid in Zingiber officinale (El-Nabarawy et al. 2015) and chitosan in safflower (Golkar et al. 2019) reduced the fresh weight of the callus. The CGR showed variation from $0.53\left(\mathrm{~mm}^{-1 a y}{ }^{-1}\right)$ at $0.5 \mathrm{mM}$ Pu to $0.17(\mathrm{~mm}$ day $^{-1}$ ) under $100 \mu \mathrm{M}$ MeJ (Table 3). For CGR, all elicitations resulted in a significant reduction compared to the control, except for 0.5 (mM) of Pu (Table 3). This result indicates the beneficiary effects of lower concentrations of $\mathrm{Pu}(0.5 \mathrm{mM})$ on motivating callus growth. Such a response is consistent with findings of cell growth and callus diameter in Hypericum perforatum (Abdollahipoor et al. 2017). It is well established that Pu stimulates not only callus cell extension but also its cell division. The nonsignificant effects of MeJ on callus growth were also reported on cultures of Zanthoxylum stenophyllum Hemsl (Biondi et al. 2004). Elicitation by these elicitors changed the color of calli to yellow-to-pale brown and pale brown after the elicitation period. The calli under Pu were more turbid. The elicitation process diminishes the friable structure of the calluses to an approximate extent. 
Table 3

The mean comparison for different studied traits of $A$. jesdianum under callus elicitation (methyl jasmonate and putrescine)

\begin{tabular}{|c|c|c|c|c|c|c|}
\hline \multicolumn{7}{|c|}{ Elicitors } \\
\hline Traits & Control & $\begin{array}{l}\text { MeJ }(25 \\
\mu \mathrm{M})\end{array}$ & $\mathrm{MeJ}(50 \mu \mathrm{M})$ & $\begin{array}{l}\text { MeJ }(100 \\
\mu \mathrm{M})\end{array}$ & $\begin{array}{l}\mathrm{Pu}(0.5 \\
\mathrm{mM}\end{array}$ & $\begin{array}{l}\mathrm{Pu}(1 \\
\mathrm{mM})\end{array}$ \\
\hline \multicolumn{7}{|c|}{ Callus related traits } \\
\hline CGR & $0.42^{\mathrm{b} \pm} 0.02$ & $\begin{array}{l}0.39^{b} \pm \\
0.02\end{array}$ & $0.19^{d} \pm 0.02$ & $\begin{array}{l}0.17^{d} \pm \\
0.03\end{array}$ & $\begin{array}{l}0.53^{\mathrm{a}} \pm \\
0.003^{-}\end{array}$ & $\begin{array}{l}0.31^{c} \pm \\
0.01\end{array}$ \\
\hline \multirow[t]{2}{*}{ RFW } & $\begin{array}{l}1.52^{\mathrm{a}} \pm \\
0.08\end{array}$ & $\begin{array}{l}1.12^{\mathrm{b}} \pm \\
0.055^{-}\end{array}$ & $0.8^{c} \pm 0.06$ & $\begin{array}{l}0.60^{d} \pm \\
0.027\end{array}$ & $\begin{array}{l}0.72^{\mathrm{dc}} \pm \\
0.002\end{array}$ & $\begin{array}{l}0.64^{d} \pm \\
0.02\end{array}$ \\
\hline & & & $\begin{array}{l}\text { Lipid } \\
\text { peroxidation }\end{array}$ & & & \\
\hline \multirow[t]{2}{*}{$\begin{array}{l}\mathrm{MDA}(\mu \mathrm{mol} \mathrm{g} \\
\left.{ }^{1} \mathrm{FW}\right)\end{array}$} & $\begin{array}{l}0.18^{c} \pm \\
0.007\end{array}$ & $\begin{array}{l}0.21^{c} \pm \\
0.05\end{array}$ & $0.33^{b} \pm 0.014$ & $\begin{array}{l}0.47^{a} \pm \\
0.018\end{array}$ & $\begin{array}{l}0.26^{b c} \pm \\
0.033\end{array}$ & $\begin{array}{l}0.53^{\mathrm{a}} \pm \\
0.05\end{array}$ \\
\hline & & & $\begin{array}{l}\text { Secondary } \\
\text { metabolites }\end{array}$ & & & \\
\hline $\begin{array}{l}\text { TPC(mg } \\
\left.\text { GAEg }{ }^{-1} \mathrm{FW}\right)\end{array}$ & $\begin{array}{l}2.86^{d} \pm \\
0.22\end{array}$ & $\begin{array}{l}3.79^{b} \pm \\
0.10\end{array}$ & $6.02^{\mathrm{a}} \pm 0.20$ & $\begin{array}{l}2.899^{\mathrm{cd}} \\
\pm 0.38\end{array}$ & $\begin{array}{l}3.54^{\mathrm{bc}} \pm \\
0.06\end{array}$ & $\begin{array}{l}3.01^{\mathrm{cd}} \pm \\
0.20\end{array}$ \\
\hline $\begin{array}{l}\text { TFD (mg QEg } \\
\left.{ }^{1} \mathrm{FW}\right)\end{array}$ & $\begin{array}{l}0.20^{d} \pm \\
0.01\end{array}$ & $\begin{array}{l}0.33^{b c} \pm \\
0.02\end{array}$ & $0.52^{\mathrm{a}} \pm 0.043$ & $\begin{array}{l}0.39^{b} \pm \\
0.02\end{array}$ & $\begin{array}{l}0.62^{\mathrm{a}} \pm \\
0.048\end{array}$ & $\begin{array}{l}0.22^{\text {cd }} \pm \\
0.007\end{array}$ \\
\hline $\begin{array}{l}\mathrm{TFL}\left(\mathrm{mg} \mathrm{QEg}{ }^{-1}\right. \\
\mathrm{FW})\end{array}$ & $\begin{array}{l}0.24^{c} \pm \\
0.008\end{array}$ & $\begin{array}{l}0.31^{\mathrm{b}} \pm \\
0.01^{-}\end{array}$ & $0.39 a \pm 0.01$ & $\begin{array}{l}0.26^{c} \pm \\
0.008\end{array}$ & $\begin{array}{l}0.27^{c} \pm \\
0.009\end{array}$ & $\begin{array}{l}0.25^{c} \pm \\
0.02\end{array}$ \\
\hline \multirow[t]{2}{*}{$\begin{array}{l}\text { Ant }\left(\mu \mathrm{mol} \mathrm{g}^{-1}\right. \\
\text { FW) }\end{array}$} & $\begin{array}{l}2.43^{\mathrm{d}} \pm \\
0.41\end{array}$ & $\begin{array}{l}8.99 a \pm \\
0.53\end{array}$ & $7.46^{\mathrm{b}} \pm 0.22$ & $\begin{array}{l}5.59^{c} \pm \\
0.29\end{array}$ & $\begin{array}{l}2.93^{\mathrm{d}} \pm \\
0.3^{-1}\end{array}$ & $\begin{array}{l}2.41^{d} \pm \\
0.1^{-}\end{array}$ \\
\hline & & & $\begin{array}{l}\text { Photosynthetic } \\
\text { pigments }\end{array}$ & & & \\
\hline $\begin{array}{l}\text { ChlT }\left(\mathrm{mg} \mathrm{g}^{-1}\right. \\
\text { DW) }\end{array}$ & $\begin{array}{l}0.15^{\mathrm{b}} \pm \\
0.01\end{array}$ & $\begin{array}{l}0.17^{\mathrm{b}} \pm \\
0.01\end{array}$ & $0.27^{a} \pm 0.03$ & $\begin{array}{l}0.16^{b} \pm \\
0.01\end{array}$ & $\begin{array}{l}0.17^{\mathrm{b}} \pm \\
0.003^{-}\end{array}$ & $\begin{array}{l}0.29^{\mathrm{a}} \pm \\
0.007\end{array}$ \\
\hline $\begin{array}{l}\mathrm{Car}\left(\mathrm{mg} \mathrm{g}^{-1}\right. \\
\text { DW) }\end{array}$ & $\begin{array}{l}0.031^{b} \pm \\
0.01\end{array}$ & $\begin{array}{l}0.038^{\mathrm{b}} \pm \\
0.04\end{array}$ & $0.059^{a} \pm 0.01$ & $\begin{array}{l}0.035^{\mathrm{b}} \pm \\
0.007\end{array}$ & $\begin{array}{l}0.045^{\mathrm{ab}} \pm \\
0.005\end{array}$ & $\begin{array}{l}0.029^{\mathrm{b}} \pm \\
0.002\end{array}$ \\
\hline
\end{tabular}

\subsubsection{Lipid peroxidation}


During the elicitation process, some processes such as lipid peroxidation of membranes lead to enhancing antioxidant enzyme activity and the activation of SMs production (Das and Roychoudhury 2014). Lipid peroxidation produces MDA as a sign of oxidative damage to scavenging ROS under elicitation (Das and Roychoudhury 2014). Callus evaluation revealed a significant increase in MDA content under treatments of MeJ and Pu. This increase varied from $0.18 \mu \mathrm{mol} \mathrm{g}^{-1} \mathrm{FW}$ in the control to $0.53 \mu \mathrm{mol} \mathrm{g}{ }^{-1} \mathrm{FW}$ in the samples treated with $1 \mathrm{mM}$ Pu (Table 3). The MDA content showed a 2.94-fold increase $(P<0.05)$ in the calluses exposed to $1 \mathrm{mM}(\mathrm{Pu})$ compared with the control cultures. In agreement with these previous studies, exposure to MeJ significantly increased the MDA content in Panax ginseng. (Ali et al. 2007) through suspension culture and other elicitors such as chitosan (Golkar et al. 2019) through callus culture. According to the results, MDA content under $1 \mathrm{mM}(\mathrm{Pu})$ was not significantly different from the control (Table 3), indicating participating effects of Pu in sustaining membrane integrity in plant cells (Yiu et al. 2009). It has been reported that exogenous application of Pu reduces the severity of oxidative damage in Allium fistulosum by increasing the antioxidant capacity of the plant (Yiu et al. 2009). This may suggest that a higher concentration ( $>0.5 \mathrm{mM} \mathrm{Pu}$ ) could act as a stressor agent on calli cells by increasing the MDA content significantly.

Plants employ a different variety of defense response pathways in response to environmental stresses such as elicitor exposure at cellular levels (Ramirez-Estrada et al. 2016). These cellular responses lead to the more production and accumulation of several SMs such as phenolics and their derivatives (Namdeo 2007; Ramirez-Estrada et al. 2016; Erb and Kliebenstein 2020). In Allium species, some studies have reported elicitation effects on some SMs and their content in the whole plant (Pirbalouti 2019; Alwan et al. 2020). However, to the best of our knowledge, no study has evaluated changes in SMs of $A$. jesdianum at a cellular level. According to the findings, using MeJ and Pu resulted in a significant increase in TPC compared to control (Table 3). The highest ( $6.02 \mathrm{mg} \mathrm{GAEg}^{-1} \mathrm{FW}$ ) and the least ( $2.86 \mathrm{mg} \mathrm{GAEg}^{-1} \mathrm{FW}$ ) contents of TPC were observed at treatments of $50 \mathrm{mM} \mathrm{MeJ}$ and control treatments, respectively (Table 3). In callus cultures treated with 25, 50, and $100 \mu \mathrm{M}$ of MeJ, the TPC showed 1.32-, 2.10-, and 1.01 -fold increases compared to control, respectively (Table 3). When treated with $50 \mu \mathrm{M}$ MeJ, callus cultures induced maximum corresponding TPC levels of $6.02 \mathrm{mg} \mathrm{GAEg}^{-1} \mathrm{FW}$, while $100 \mu \mathrm{M}$ MeJ resulted in inhibited levels with the value $2.89 \mathrm{mg} \mathrm{GAEg}^{-1} \mathrm{FW}$ on callus culture (Table 3). Similarly, the enhancing effect of lower concentrations of MeJ on total phenolics induction was reported on other species through callus cultures of Zanthoxylum stenophyllum (Biondi et al. 2004) and suspension cultures in Artemisia absinthium L. (Ali et al. 2015), Ajuga bracteosa (Saeed et al. 2017) Polygonum multiflorum (Thiruvengadam, et al. 2016), and Thevetia peruviana (Mendoza et al. 2018).

The callus treated with 0.5- and 1-mM Pu indicated 1.23-1.05-fold increases in TPC content, respectively (Table 3). The effect of in vitro elicitation of Pu on TFC accumulation has been rarely reported in literature review; however, the results showed its positive effect on increasing some phenolic acids (e.g., ferulic, caffeoylquinic, and sinapic acids) in Gardenia Jasminoides L. by the concentration of $0.5 \mathrm{mg} \mathrm{L}^{-1}$ of it (Al-Maameri et al. 2020). The TFD content showed a significant increase compared to the control (0.2 mg QE g ${ }^{-1} \mathrm{FW}$ ) up to 0.52 ( $\mathrm{mg} \mathrm{QE} \mathrm{g}^{-1} \mathrm{FW}$ ) under $50 \mathrm{mM}$ of MeJ (Table 3). For Pu elicitation, only the lower 
concentration level $(0.5 \mathrm{mM})$ showed a significant difference with control (Table 3). This finding was like the positive effects of MeJ increase in the total flavonoids of Hypericum perforatum (Wang et al. 2015) and Thevetia peruviana (Mendoza et al. 2018) through callus culture and cell suspension culture of Taxus baccata (Jalalpour et al. 2014) and Ajuga bracteosa (Saeed et al. 2017). Under in vitro elicitations, an increase in TFD content suggested higher rates of its synthesis and accumulation. This can be attributed to the possible positive effects of elicitors on the enhanced expression of the genes, contributing to the synthesis pathway of total flavonoids (e.g., phenylpropanoid) (Talukder et al. 2016).

The content of TFL showed variation from $0.24\left(\mathrm{mg} \mathrm{QEg}^{-1} \mathrm{FW}\right)$ in control to 0.39 ( $\mathrm{mg} \mathrm{QE} \mathrm{g}^{-1} \mathrm{FW}$ ) under $50 \mu \mathrm{M} \mathrm{MeJ}$ (Table 3). No significant differences were observed between the two levels of Pu with control for the TFL content. It may be concluded that Pu elicitation did not provide adequate efficiency for increasing TFL in calluses of $A$. jesdianum and thus other concentrations should be applied. Reviewing the literature shows no study on the elicitation effects of Pu (as a compound in polyamines) on TFD and TPC under callus culture. Polyamines as putrescine had a significant effect on the potential of plant regeneration and accumulation of flavonols, hydroxybenzoic, and hydroxycinnamic acid derivatives in Cucumis anguria L. (Thiruvengadam and Chung 2015). Similarly, the effect of PAs increased the amount of withanolides in Withania somnifera plants that were regenerated under in vitro conditions (Sivanandhan et al. 2011). In jojoba plants, putrescine (50 ppm) significantly increased total phenolics content, total flavonoids, tannin content, and antioxidant activity (Taha et al. 2015). Ghareib and Hanfy Ahmed (2005) reported that putrescine foliar application (1-2 ppm) improved total phenolic compounds in Pisum sativum shoots (Gharib and Hanafy Ahmed 2005).

Anthocyanins are a group of water-soluble flavonoids that are produced at one end of the flavonoid biosynthesis pathway in the cytoplasm and enter the cells actively or separately by glutathione pump (Castañeda-Ovando et al. 2009). AnthocyaninS production is affected under different environmental elicitors (Castañeda-Ovando, et al. 2009). In the present study, elicitation by MeJ and Pu increased the in vitro accumulation of anthocyanin in the $A$. jesdianum calli (Table 3 ). Its values varied from $2.43 \mu \mathrm{mol} \mathrm{g}^{-}$ ${ }^{1} \mathrm{FW}$ at control condition to $8.99 \mu \mathrm{mol} \mathrm{g}{ }^{-1} \mathrm{FW}$ at $25 \mathrm{mM}$ MeJ. Higher concentrations of MeJ (50 and 100 $\mu \mathrm{M})$ showed a descending trend for Ant rather than $25 \mu \mathrm{M}(\mathrm{MeJ})$ (Table 3). The results of this study are consistent with those of Ram et al. (2013) and Suan See et al. (2011), who reported that the quantity of anthocyanin accumulation depends on MeJ concentration in Rosa hybrida and Melastoma malabathricum, respectively. The additional result obtained indicated that a concentration of $50 \mu \mathrm{M} \mathrm{MeJ}$ was the best that could induce the highest pigment production and was used in this study.

According to Suan See et al. (2011), biosynthesis and accumulation of anthocyanin could be stimulated by MeJ elicitation via induction of particular enzymes such as catalyzes. Besides, synthetic pathways for anthocyanin biosynthesis or increase the gene(s) expression of this specialized metabolite biosynthesis are triggered by MeJ elicitation (Ram et al. 2011). The concentration of $0.5 \mathrm{mM}$ Pu led to a 1.21 -fold increase in anthocyanins rather than control, but the higher concentration ( $1 \mathrm{mM} \mathrm{Pu})$ did not have any significant effect compared to the control (Table 3). This finding was similar to the elicitation effects of Pu on anthocyanin production of Daucus carota under callus culture (Sudha et al. 2003). Therefore, at 
higher concentrations, both elicitors had an inhibitory or non-significant effect on Ant content in $A$. jesdianum. Among these two elicitors, MeJ acted as a better inducer of anthocyanin biosynthesis in $A$. jesdianum callus cultures than Pu. The novel results from the present study show that callus cultures of A.jesdianm under elicitation could be considered as an efficient way for these valuable pigments production.

A variety of environmental factors, as elicitors, affect the synthesis and accumulation of phytochemical compounds such as phenolic compounds, which are the best oxygen radical scavengers (Dias et al. 2016). The significant increase in phenolics content may be compromised by the inducing effect on trigging effects of MeJ and Pu on signal transduction pathways. These effects, in turn, speed up enzyme catalysis and lead to the formation of specific compounds such as flavonoids, flavonols, and anthocyanins in A. jesdianum.

Totally, the medium concentration of $\mathrm{MeJ}(50 \mu \mathrm{M})$ and a lower concentration of $\mathrm{Pu}(0.5 \mathrm{mM})$ showed an enhancement effect on the contents of phenolics, flavonoids, flavonols, and anthocyanin. This result could be attributed to higher production of trans-cinnamate as a product of L-phenylalanine deamination by phenylalanine ammonia-lyase enzyme and more convention of trans-cinnamate to different SMs under lower concentrations of elicitors (Alrawaiq and Abdullah 2014). In this regard, the following factors have significant effects on the trends of the elicitation process: the differences in chemical characteristics of elicitors, its preparation source and concentration, exposure time of elicitation, age and type of explant for culture, growth regulations in media culture and nutrition composition, and its interaction with plant species and genotypes (Namdeo 2007; Narayani and Srivastava 2017). Considering that the production of plant SMs is strongly controlled by signaling events and environmental factors, a fine and one-by-one analysis might be required to obtain a deeper understanding of the type of their modulation effects in different plant species at the callus level.

\subsubsection{Photosynthetic pigments}

Information about photosynthetic pigments (chlorophyll and carotenoids) action under in vitro elicitation provides useful information about their efficiency on photochemical processes at this stage. According to the findings, these two elicitors provided an effective strategy for enhanced production of these pigments under callus cultures of $A$. jesdianum. Total chlorophyll content demonstrated a significant increase under $50 \mathrm{~mm} \mathrm{MeJ}\left(0.27 \mathrm{mg} \mathrm{g}^{-1} \mathrm{DW}\right)$ and $1 \mathrm{mM} \mathrm{Pu}\left(0.29 \mathrm{mg} \mathrm{g}^{-1} \mathrm{DW}\right.$ ) (Table 3) compared to the control (Table 3). The highest $\left(0.27 \mathrm{mg} \mathrm{g}^{-1} \mathrm{DW}\right)$ and the least $\left(0.002 \mathrm{mg} \mathrm{g}^{-1} \mathrm{DW}\right)$ contents for ChlT were for 50 $\mu \mathrm{M}(\mathrm{MeJ})$ and $1 \mathrm{mM} \mathrm{Pu}$, respectively (Table 3). This increase under $50 \mu \mathrm{M}$ MeJ could be due to chlorophyllase activity stimulation under MeJ elicitation (Hanaka et al. 2015). Few studies have shown the changes of carotenoids content by cell tissue culture strategies. The effects of MeJ have been evaluated on the callus culture of Cleome rosea (de Rocha et al. 2015); nevertheless, no studies have been done about Pu elicitation on carotenoids content in callus culture. In carotenoids, elicitation by MeJ at $50 \mu \mathrm{M}$ showed a significant increase (1.9-fold) compared to control (Table 3). Other concentrations of MeJ and Pu elicitations showed no significant difference with control (Table 3). According to our 
literature, no study demonstrated elicitation effects of Pu on carotenoids content in callus level. According to this finding, selected dosages of Pu in these studies did not stimulate the increase in carotenoids at the callus level. Although the responses of accumulation of carotenoids were dependent on both MeJ and Pu concentrations, more studies are needed to find the exact effects of Pu on activation of carotenoids pathway under cellular level.

\section{.3.5. DPPH activity}

To neutralize the effect of stresses caused through the elicitation process, the plant cells employ antioxidative activities in different ways such as enhancement of SMs (Golkar et al. 2019; Nabi et al. 2021). In this study, antioxidant activity was determined as DPPH radical scavenging activity. The highest $(86.40 \%)$ and the least $(66.31 \%)$ radical scavenging activities were found in callus cultures treated with $100 \mathrm{mM} \mathrm{MeJ}$ and control conditions, respectively (Fig. 2). Callus cultures treated with $50 \mathrm{mM}$ and 100 $\mathrm{mM}$ of MeJ showed no significant difference for reactive scavenging ability through the DPPH method. The DPPH activity under two different concentrations of Pu showed no significant effect for DPPH activity compared to control conditions (Fig. 2). It was observed that $A$. jesdianum calluses had a dosedependent DPPH radical scavenging activity under MeJ elicitation (Fig. 2). This result suggests $A$. jesdianum is a good free radical scavenger under elicitation. Similarly, the increase in antioxidant activity of callus cells (e.g., DPPH method) was observed under MeJ elicitation in different cell culture techniques (Ali et al. 2007; Ho et al. 2020).

\subsection{Correlation between different traits}

The simple correlation among studied traits is presented in Table 4. A negative and significant correlation was found between RWC with TFD $\left(-0.46^{\star \star}\right)$ and TFL $\left(-0.35^{\star \star}\right)$. The lipid peroxidation content as MDA showed a negative and significant correlation with RWC $\left(-0.64^{\star \star}\right)$ and CGR $\left(-0.53^{\star \star}\right)$ (Table 5). This finding shows the importance of cell wall integrity on retaining cell water content and its growth under cellular conditions. The antioxidant activity (DPPH method) showed positive and significant correlation with TFL $\left(0.43^{\star \star}\right), \operatorname{TPC}\left(0.33^{\star \star}\right)$, and ChIT $\left(0.37^{\star \star}\right)$. The antioxidant activity through the DPPH method was found to be mainly TPC $\left(0.33^{\star \star}\right)$ and TFL $\left(0.43^{\star \star}\right)$, depending on callus cultures treated with different elicitors. Furthermore, a positive correlation between TPC and TFL with DPPH suggests that the elicitation process increased the antioxidant activity of $A$. jesdianum through more accumulation of TPC and TFL in callus culture. 
Table 4

The simple correlation coefficients for different morpho- biochemical traits under elicitation by chitosan and gibberellic acid.

\begin{tabular}{|c|c|c|c|c|c|c|c|c|c|c|}
\hline & RFW & CGR & DPPH & TFD & TFL & TPC & ChIT & Car & MDA & Ant \\
\hline $\mathrm{RFW}^{\mathrm{l}}$ & 1 & & & & & & & & & \\
\hline CGR & $0.39^{*}$ & 1 & & & & & & & & \\
\hline DPPH & $-0.31^{*}$ & $-0.59^{* *}$ & 1 & & & & & & & \\
\hline TFD & $-0.46^{\star \star}$ & 0.04 & 0.17 & 1 & & & & & & \\
\hline TFL & $-0.35^{\star}$ & $-0.45^{* *}$ & $0.43^{\star \star}$ & $0.32^{\star}$ & 1 & & & & & \\
\hline TPC & -0.09 & -0.26 & $0.33^{*}$ & 0.04 & -0.2 & 1 & & & & \\
\hline ChlT & 0.16 & $-0.44^{\star *}$ & $0.37^{*}$ & 0.05 & 0.17 & $0.61^{* *}$ & 1 & & & \\
\hline Car & -0.09 & 0.24 & -0.2 & 0.17 & -0.03 & 0 & -0.16 & 1 & & \\
\hline MDA & $-0.64^{\star *}$ & $-0.52^{* *}$ & 0.28 & 0.05 & 0.15 & -0.11 & $-0.31^{*}$ & -0.02 & 1 & \\
\hline Ant & $0.87^{\star \star}$ & 0.18 & -0.25 & $-0.46^{* \star}$ & -0.29 & 0.16 & $0.43^{* *}$ & -0.19 & $-0.66^{* *}$ & 1 \\
\hline
\end{tabular}

\section{Conclusion}

Plant cell cultures have been perceived as an attractive method for producing SMs under controlled conditions. This study optimized seed germination, callus induction, and the effects of two different elicitors (MeJ and $\mathrm{Pu}$ ) on the enhancement of different phenolics and callus related traits in $A$. jesdianum, by the first. The findings showed higher efficiency of MeJ than Pu for increasing different secondary metabolites and antioxidant activity in calli of $A$. jesdianum. The superiority of Pu elicitation was increasing callus growth and the contents of two studied pigments (carotenoids and chlorophyll). This study suggests evaluating other different concentrations of Pu for callus elicitation. The concentration of $50 \mu \mathrm{M} \mathrm{MeJ}$ showed the best selective dose for enhancing the contents of phenolic compounds in A. jesdianum through callus culture. This study could lead to introducing a new way to improve the production of the beneficial phytochemical compounds from undifferentiated callus cells in the threatened medicinal plant of $A$. jesdianum.

\section{Abbreviations}


BAP : 6-Benzylaminopurine; 2,4-D: 2,4-Dichlorophenoxyacetic acid; FW: Fresh weight; DW: Dry weight; NAA: a-Naphthaleneacetic acid; MS: Murashige and Skoog; MeJ: Methyl jasmonate; Pu: Putrescine; TPC: total phenolics content; TFD: total flavonoids; TFL: total flavonols; DPPH: 2,2-diphenyl-1-picrylhydrazyl.

\section{Declarations}

\section{Acknowledgments}

The authors would like to thank Research Institute for Biotechnology and Bioengineering, Isfahan University of Technology, Isfahan, Iran.

\section{Declarations}

The authors do not have conflicts of interest in regard to this research or its funding.

\section{References}

1. Abbas MS, El-Shabrawi HM, Soliman AS, Selim MA (2018) Optimization of germination, callus induction, and cell suspension culture of African locust beans Parkia biglobosa (Jacq.) Benth. J Genet Eng Biotechnol 16(1):191-201

2. Abdollahipoor M, Kalantari S, Azizi M, Saadat YA (2017) Effects of methyl jasmonate and chitosan on shoot and callus growth of Iranian Hypericum perforatum L. in vitro Cultures. J Medicinal Plants By-Products 6(2):165-172

3. Ali MB, Hahn EJ, Paek KY (2007) Methyl jasmonate and salicylic acid induced oxidative stress and accumulation of phenolics in Panax ginseng bioreactor root suspension culture. Molecules 12:607621

4. Ali M, Abbasi BH, Ali GS (2015) Elicitation of antioxidant secondary metabolites with jasmonates and gibberellic acid in cell suspension cultures of Artemisia absinthium L. Plant Cell Tissue Org Cult 120(3):1099-1106

5. Al-Maameri AAK, Almyali AAH (2020) Effect of putrescine and type of light in callus of Gardenia Jasminoides L. content from some effective medical compounds. In IOP Conference Series: Materials Science and Engineering (Vol. 871, No. 1, p. 012017). IOP Publishing

6. Alrawaiq NS, Abdullah A (2014) A review of flavonoid quercetin: metabolism, bioactivity and antioxidant properties. Int J PharmTech Res 6(3):933-941

7. Alwan AH, Twaij BM, Alwan BH (2020) Induction of Allium sativum tissue culture by I-methionine and gibberellic acid and study of the effect of extract against fungal / plant pathogens. Plant Arch 20(1):2839-2844

8. Amoakoh O, Nortey D, Sagoe F, Amoako P, Jallah C (2017) Effects of pre-sowing treatments on the germination and early growth performance of Pouteria campachiana. Forest Sci Technol 13:83-86 
9. Bekheet SA, Taha HS, Solliman ME (2006) Salt tolerance in tissue culture of onion (Allium cepa L.). Arab J Biotech 9(3):467-476

10. Bhat R (2020) Bioactive Compounds of Allium Species. Bioactive Compounds in Underutilized Vegetables and Legumes, 1-20

11. Biondi S, Antognoni F, Perellino NC, Sacchetti G, Minghetti A, Poli F (2004) Medium composition and methyl jasmonate influence the amount and spectrum of secondary metabolites in callus cultures of Zanthoxylum stenophyllum. Hemsl Plant Biosys 138(2):117-124

12. Castañeda-Ovando A, de Lourdes Pacheco-Hernández M, Páez-Hernández ME, Rodríguez JA, GalánVidal CA (2009) Chemical studies of anthocyanins: A review. Food Chem 113(4):859-871

13. Chen D, Shao Q, Yin L, Younis A, Zheng B (2019) Polyamine function in plants: metabolism, regulation on development, and roles in abiotic stress responses. Front Plant Sci 9:1945

14. da Rocha AS, Rocha EK, Alves LM, de Moraes BA, de Castro TC, Albarello N, Simões-Gurgel C (2015) Production and optimization through elicitation of carotenoid pigments in the in vitro cultures of Cleome rosea Vahl (Cleomaceae). J Plant Biochem Biotechnol 24(1):105-113

15. Das K, Roychoudhury A (2014) Reactive oxygen species (ROS) and response of antioxidants as ROSscavengers during environmental stress in plants. Front Environ Sci 2:53

16. Dias MI, Sousa MJ, Alves RC, Ferreira IC (2016) Exploring plant tissue culture to improve the production of phenolic compounds: A review. Ind crops Prod 82:9-22

17. Dixit V, Rai SP, Chaudary BR (2013) Allium sativum: four-step approach to efficient micropropagation. Int J Innov Biol Res 2(1):6-14

18. Dorosti N, Zarabi S, Ahmadi S, Rostami R, Rashidi Pour M (2017) Evaluation of anticancer activity methanolic extract of Allium Jesdianum and Nectaroscordeum Coelzi against HeLa and K562 cell lines. Yafte 19(1):31-41

19. El-Nabarawy MA, El-Kafafi SH, Hamza MA, Omar MA (2015) The effect of some factors on stimulating the growth and production of active substances in Zingiber officinale callus cultures. Ann Agric Sci 60(1):1-9

20. Erb M, Kliebenstein DJ (2020) Plant secondary metabolites as defenses, regulators, and primary metabolites: the blurred functional trichotomy. Plant Physiol 184(1):39-52

21. Gabr AM, Ghareeb H, El Shabrawi HM, Smetanska I, Bekheet SA (2016) Enhancement of silymarin and phenolic compound accumulation in tissue culture of Milk thistle using elicitor feeding and hairy root cultures. J Genet Eng Biotechnol 14(2):327-333

22. Gharib A, Hanafy Ahmed A (2005) Response of pea (Pisum sativum, L.) to foliar application of putrescine, glucose, folia feed D and silicon. J Agric Sci Mansoura Univ 30:7563-7579

23. Golkar P, Taghizadeh M, Yousefian Z (2019) The effects of chitosan and salicylic acid on elicitation of secondary metabolites and antioxidant activity of safflower under in vitro salinity stress. Plant Cell Tissue Org Cult 137(3):575-585 
24. Golkar P, Taghizadeh M (2018) In vitro evaluation of phenolic and osmolite compounds, ionic content, and antioxidant activity in safflower (Carthamus tinctorius L.) under salinity stress. Plant Cell Tissue Org Cult 134: 357-368

25. Hanaka A, Maksymiec W, Bednarek W (2015) The effect of methyl jasmonate on selected physiological parameters of copper-treated Phaseolus coccineus plants. Plant Growth Regul 77(2):167-177

26. Hara M, Oki K, Hoshino K, Kuboi T (2003) Enhancement of anthocyanin biosynthesis by sugar in radish (Raphanus sativus) hypocotyl. Plant Sci 164:259-265

27. Heath RL, Packer L (1968) Photoperoxidation in isolated chloroplasts: I. Kinetics and stoichiometry of fatty acid peroxidation. Arch Biochem Biophys 125:189-198

28. Ho TT, Murthy HN, Park SY (2020) Methyl jasmonate induced oxidative stress and accumulation of secondary metabolites in plant cell and organ cultures. Int J Mol Sci 21(3):716

29. Jalalpour Z, Shabani L, Afghani L, Sharifi-Tehrani M, Amini SA (2014) Stimulatory effect of methyl jasmonate and squalestatin on phenolic metabolism through induction of LOX activity in cell suspension culture of yew. Turk J Biol 38(1):76-82

30. Jiménez Bremont JF, Marina M, Guerrero-Gonzalez MDLL, Rossi FR, Sánchez-Rangel D, RodríguezKessler M, Ruiz OA, Gárriz A (2014) Physiological and molecular implications of plant polyamine metabolism during biotic interactions. Front in Plant Sci 5:95

31. Kalantari H, Shamsi Ehsan T, Samimi A, Kheradmand P, Shirani M, Zeidooni L (2018) Histopathological and biomedical parameters determination in the protective effect of hydroalcoholic extract of Allium jesdianum on hepatotoxicity induced by bromobenzene in mice. Iran $\mathrm{J}$ of Pharm Sci 14:15-24

32. Kamenetsky R, Gutterman Y (2000) Germination strategies of some Allium species of the subgenus Melanocrommuyum from arid zone of Central Asia. J Arid Environ 45:61-71

33. Khar A, Bhutani RD, Yadav N, Chowdhury VK (2005) Effect of explant and genotype on callus culture and on regeneration in onion (Allium Cepa L.). Akdeniz Univ Ziraat Fak Derg 18(3):397-404

34. Klimek-Chodacka M, Kadluczka D, Lukasiewicz A, Malec-Pala A, Baranski R, Grzebelus E (2020) Effective callus induction and plant regeneration in callus and protoplast cultures of Nigella damascena L. Plant Cell Tissue Org Cult 143(3):693-707

35. Kyung KH (2012) Antimicrobial properties of allium species. Curr Opin Biotechnol 23:142-147

36. Li Z, Burritt DJ (2003) Changes in endogenous polyamines during the formation of somatic embryos from isogenic lines of Dactylis glomerata L. with different regenerative capacities. Plant Growth Regul 40:65-74

37. Lichtenthaler HK, Buschmann C (2001) Extraction of phtosynthetic tissues: chlorophylls and carotenoids. Current protocols in food analytical chemistry 1, F4. 2.1-F4. 2.6

38. Lorigooini Z, Ayatollahi SA, Amidi S, Kobarfard F (2015) Evaluation of anti-platelet aggregation effect of some Allium species. Iranian J Pharm Res 14:1225 
39. Matkowski A (2008) Plant in vitro culture for the production of antioxidants-a review. Biotechnol Adv 26(6):548-560

40. Mendoza D, Arias JP, Cuaspud O, Ruiz O, Arias M (2018) Methyl jasmonate/salicylic acid enhanced flavonoid production and change metabolites profile in Thevetia peruviana cell culture. In vitro Cell Dev Biol Plant 54:4-27

41. Miliauskas $G$, Venskutonis $P$, Van Beek $T$ (2004) Screening of radical scavenging activity of some medicinal and aromatic plant extracts. Food Chem 85:231-237

42. Monemi MB, Kazemitabar SK, Khaniki GB, Yasari E, Sohrevardi F, Pourbagher R (2014) Tissue culture study of the medicinal plant leek (Allium Ampeloprasum L). Int J Mol Cell Med 3(2):118

43. Mulabagal V, Chen-Yue L, Shu-Fung L, Satish MN, Chien YL, Hsin-Sheng T (2004) Studies on the production of some important secondary metabolites from medicinal plants by plant tissue cultures. Bot Bull Acad Sin 45:1-22

44. Murashige $T$, Skoog $F$ (1962) A revised medium for rapid growth and bio assays with tobacco tissue cultures. Physiol Plant 15(3):473-497

45. Nabi N, Singh S, Saffeullah P (2021) Responses of in vitro cell cultures to elicitation: regulatory role of jasmonic acid and methyl jasmonate: a review. In Vitro Cell Dev Biol-Plant, pp.1-15

46. Namdeo AG (2007) Plant cell elicitation for production of secondary metabolites: a review. Pharmacogn Rev (1):69-79

47. Narayani M, Srivastava S (2017) Elicitation: a stimulation of stress in in vitro plant cell/tissue cultures for enhancement of secondary metabolite production. Phytochem Rev 16(6):1227-1252

48. Pirbalouti AG (2019) Phytochemical and bioactivity diversity in the extracts from bulbs and leaves of different populations of Allium jesdianum, a valuable underutilized vegetable. Acta Sci Pol Hortorum Cultus 18:115-122

49. Rangan P, Subramani R, Kumar R, Singh AK, Singh R (2014) Recent advances in polyamine metabolism and abiotic stress tolerance. Bio Med Res Int 2014:1-9

50. Ram M, Prasad KV, Singh SK, Hada BS, Kumar S (2013) Influence of salicylic acid and methyl jasmonate elicitation on anthocyanin production in callus cultures of Rosa hybrida L. Plant Cell Tissue Org Cult 113(3):459-467

51. Rouis-Soussi LS, El Ayeb-Zakhama A, Mahjoub A, Flamini G, Jannet HB, Harzallah-Skhiri F (2014) Chemical composition and antibacterial activity of essential oils from the Tunisian Allium nigrum $\mathrm{L}$. EXCLI J 13:526

52. Saeed S, Ali H, Khan T, Kayani W, Khan MA (2017) Impacts of methyl jasmonate and phenyl acetic acid on biomass accumulation and antioxidant potential in adventitious roots of Ajuga bracteosa Wall ex Benth., a high valued endangered medicinal plant. Physiol Mol Biol Plants 23(1):229-237

53. Singh A, Dwivedi $P$ (2018) Methyl-jasmonate and salicylic acid as potent elicitors for secondary metabolite production in medicinal plants: A review. J Pharmacogn Phytochem 7(1):750-757 
54. Suan See K, Bhatt A, Lai Keng C (2011) Effect of sucrose and methyl jasmonate on biomass and anthocyanin production in cell suspension culture of Melastoma malabathricum (Melastomaceae). Revista de Biol Tropic 59(2):597-606

55. Singleton VL, Orthofer R, Lamuela-Raventós RM (1999) Analysis of total phenols and other oxidation substrates and antioxidants by means of folin-ciocalteu reagent. Methods Enzymol 299:152-178

56. Sivanandhan G, Mariashibu TS, Arun M, Rajesh M, Kasthurirengan S, Selvaraj N, Ganapathi A (2011) The effect of polyamines on the efficiency of multiplication and rooting of Withania somnifera (L.) Dunal and content of some withanolides in obtained plants. Acta Physiol Plant 33(6):2279

57. Smetanska I (2008) Production of secondary metabolites using plant cell cultures. Food Biotechnol 111:187-228

58. Stelmaszczuk M, Kozak D (2013) Micropropagation of Allium neapolitanum Cirillo. Acta Sci Pol Hortorum Cultus 12:193-206

59. Sudha G, Ravishankar GA (2003) Elicitation of anthocyanin production in callus cultures of Daucus carota and the involvement of methyl jasmonate and salicylic acid. Acta Physiol Plant 25:249-256

60. Taha LS, Taie HA, Hussein M (2015) Antioxidant properties, secondary metabolites and growth as affected by application of putrescine and moringa leaves extract on jojoba plants. J Applied Pharmaceutical Science 5:030-036

61. Talukder P, Talapatra S, Ghoshal N, Sen Raychaudhuri S (2016) Antioxidant activity and highperformance liquid chromatographic analysis of phenolic compounds during in vitro callus culture of Plantago ovata Forsk. and effect of exogenous additives on accumulation of phenolic compounds. J Sci Food Agric 96:232-244

62. Thiruvengadam M, Chung IM (2015) Phenolic compound production and biological activities from in vitro regenerated plants of gherkin (Cucumis anguria L.). Electron J Biotechnol 18(4):295-301

63. Thiruvengadam M, Rekha K, Rajakumar G, Lee TJ, Kim SH, Chung IM (2016) Enhanced production of anthraquinones and phenolic compounds and biological activities in the cell suspension cultures of Polygonum multiflorum. Int J Mol Sci 17(11):1912

64. Vanisree M, Lee CY, Lo SF, Nalawade SM, Lin CY, Tsay HS (2015) Studies on the production of some important secondary metabolites from medicinal plants by plant tissue cultures. Bot Bull Acad Sin 45(1):1-22

65. Wang J, Qian J, Yao L, Lu Y (2015) Enhanced production of flavonoids by methyl jasmonate elicitation in cell suspension culture of Hypericum perforatum. Bioresour Bioprocess 2(1): p.5

66. Yiu JC, Juang LD, Fang DYT, Liu CW, Wu SJ (2009) Exogenous putrescine reduces flooding-induced oxidative damage by increasing the antioxidant properties of welsh onion. Sci Hortic 120(3):306314

67. Yue W, Ming Q, Lin B, Rahman K, Zheng CJ, Han T, Qin LP (2016) Medicinal plant cell suspension cultures: pharmaceutical applications and high-yielding strategies for the desired secondary metabolites. Crit Rev Biotechnol 36:215-232 
68. Zdravković-Korac S, Milojević J, Tubić L, Ćalić-Dragosavac D, Mitić N, Vinterhalter B (2010) Somatic embryogenesis and plant regeneration from root sections of Allium schoenoprasum $\mathrm{L}$. Plant Cell Tissue Org Cult 101(2):237-244

\section{Figures}

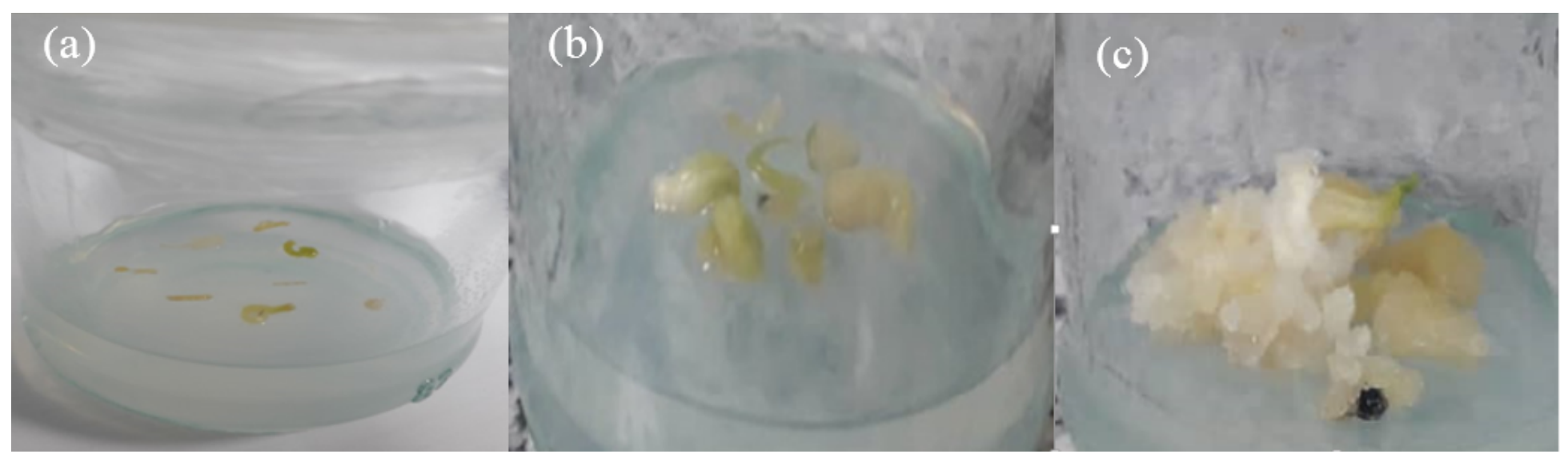

\section{Figure 1}

Hypocotyl culture (a) and callus induction from hypocotyl (b) and seed (c) explants of A. jesdianum on Murashige and Skoog medium supplemented with 1.0 (mg L -1) 2,4- D+1.0 (mg L -1) Kin (a), 1 (mg L-1) $\mathrm{NAA}+0.5$ (mg L -1) BAP (b).

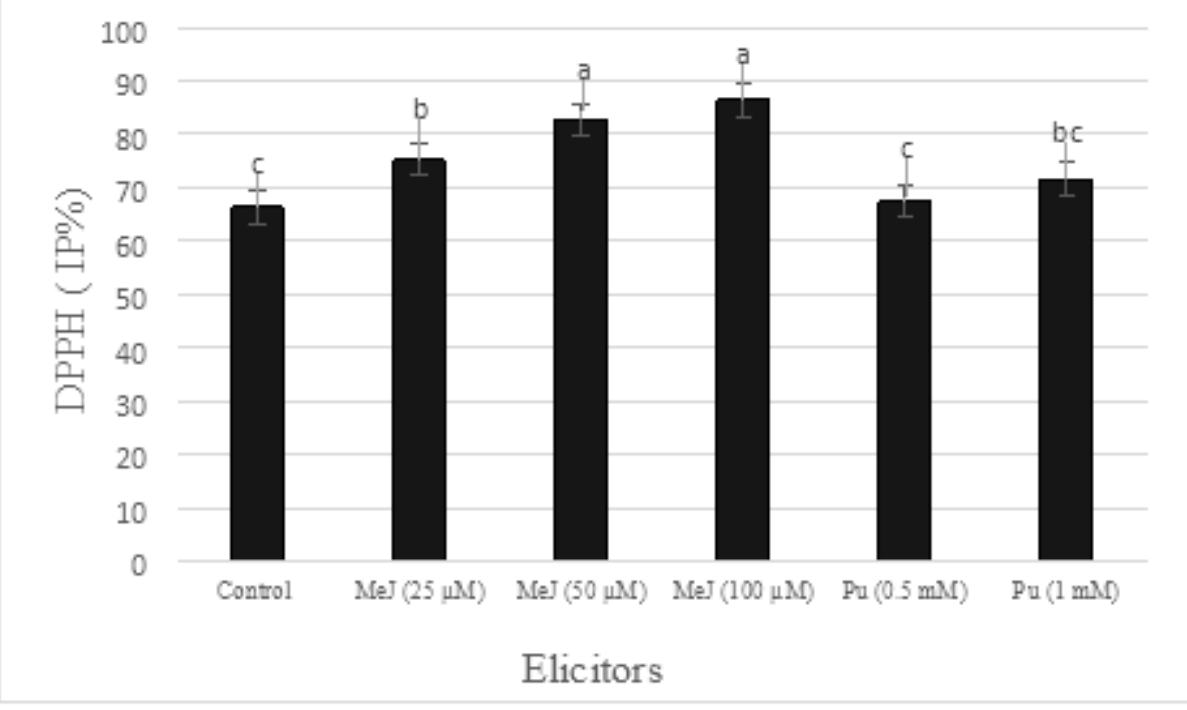

\section{Figure 2}

The means for DPPH activity ( \pm standard deviation) in different elicitors (methyl jasmonate and putrescine) under in vitro callus culture in $A$. jesdianum. 